\section{Skylab coming down}

Orlicinls at the US National Aeronautics and Space Administration are concerned that Skylab, last used in 1974 and still, at 85 tons, the largest manmade object in carth orbit, could fall to earth later this year.

Originally it was planned that Skylab would stay in orbit until 1980 . when a manned space shuttle could attach a rocket motor to it that would send it into a higher orbit, or initiate a controlled re-entry.

Recent calculations, however, indicate that Skylab, which cost $\$ 294$ million to launch, could crash into the atmosphere later this year, and NASA officials are now working on a plan to command the still-operable steering rockets to send Skylab into a controlled tumble that would speed up re-entry.

The manoeuvre would be carefully calculated to bring the station back to earth on a steep descent over a broad area such as the Indian Ocean or the South Pacific.

\title{
Letter from Sakharov and Meiman
}

IN October 1977, the US Association for Computing Machinery informed their Soviet opposite numbers that they would not cooperate with or sponsor international conferences in the Soviet Union until the Soviet attitude to human rights, exemplified by the case of Anatolii Shcharanskii, improved. Recently the ACM received the following message:

To the Association for Computing

Machinery; to US scientists and engineers in computer technology

\section{Distinguished Gentlemen,}

We'd like to express to your our deep gratitude for your resolute actions on behalf of Anatolii Shcharanskii. You have hit just the right nail. The Soviet authorities extremely appreciate the cooperation in science and technology, thus, there is nothing to induce them so factually and effectively as a refusal to maintain

\section{this cooperation.}

We'd feel happy if your actions were followed suit by physicists on behalf of Professor Yurii Orlov and Andrei Tverdokhlebov, by biologists and medical specialists on behalf of Sergei Kovalev, as well as by writers and editors on behalf of Aleksandr Ginzburg.

Your couragcous and noble stand is not simply ethically the best but the only practical one. Do not believe and do not take seriously any assertion that your decision allegedly could only embitter the Soviet authoritics and aggravate the situation of Soviet scientists. Do not doubt that vour human and professional solidarity will bring positive results.

Nobel prize winner, Academician A. Sakharov

Professor of Mathematics N. Meiman
CORN (maize) is the principal grain crop of the United States. Cash receipts from corn in the US in 1969 were nearly twice as much as for soybeans, and almost three times as much as for wheat. Peanuts (groundnuts) netted only $7 \%$ of the dollar value for corn. They have since become nationally prominent for presidential reasons. Peanuts, like soybeans, are legumes; they fix nitrogen and their seeds are good sources of proteins. Peanut protein is better balanced with respect to amino acids than is corn protein, but it is low in lysine, methionine and threonine.

Corn, in damp weather, and peanuts are good hosts for the growth of a mould, Aspergillus flavus, that produces aflatoxin, a potent carcinogen. The Food and Drug Administration (FDA) and the 'Delaney Clause' smiled benignly on aflatoxin, which is produced by God rather than the chemical industry, and is therefore not bannable. An 'action level' of $20 \mathrm{ppb}$ of aflatoxin is used as a guideline for regulation. This level is carcinogenic in laboratory animals. In 1974, the FDA proposed to replace this level by a tolerance of $15 \mathrm{ppb}$ for peanut products. Presumably this was intended to lower the cancer risk from aflatoxin somewhat, but the modest retreat is scarcely in accordance with the principle of total exclusion so sternly embodied in the Delaney Clause.

On 14 November, an FDA spokesman announced that 66 life-time cancers per 100,000 persons could develop from normal or expected ingestion of aflatoxin-contaminated pea- nut and corn products. Presumably this figure would correspond to about one case per 100,000 persons per year. It was based on a combined estimated consumption of $2 \mathrm{ppb}$ of aflatoxin from peanuts and $10 \mathrm{ppb}$ from corn

\section{Corn and Peanuts}

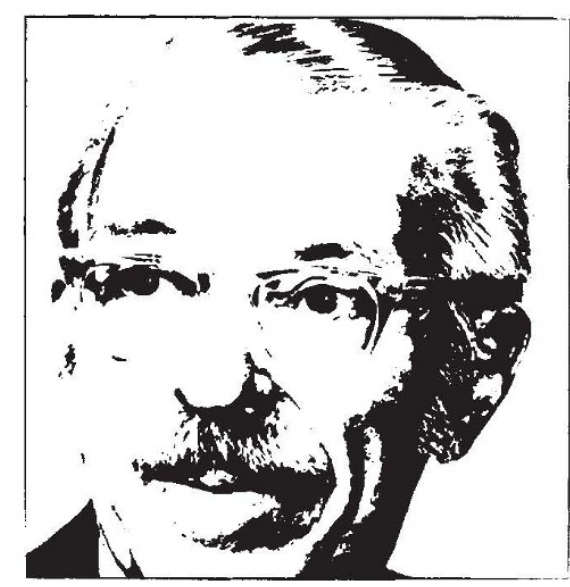

\section{THOMAS H. JUKES}

products. This cancer rate may be compared with about 33 per 100,000 for lung cancer deaths, usually largely attributed to cigarette smoking, and about 168 for all US deaths from cancer. The estimate for aflatoxin corresponds to about 2,000 cancer cases for the entire US population.

1 assessed the cancer hazard from diethylstilbestrol (DES) in beef production as not more than one case in 2.500 years in the entire US popula- tion, hased on pessimistic figures. This estimate, for some reason or other, was not challenged by the FDA lawyers who cross-examined me on 4 November at the hearings on DES in meat production. Perhaps this rather striking difference between hazards from DES and aflatoxin should be pondered by the FDA in setting priorities on bureaucratic regulations.

Aflatoxin should also be considered by vegetarians who tell us that we should eat corn, rather than feeding it to cattle, because we need to be less wasteful of food. The same school of thought advocates eating plant proteins, such as those of soybeans and peanuts, as replacements for beef and pork. However, when cattle and pigs eat corn and other feeds that contain injurious substances, they may filter them out, excrete them or metabolise them, especially if they are watersoluble. Being in a high position on the 'food chain' may have its advantages, even though we are frequently told that this is not the case.

The most active substances that inhibit mould growth belong to the antifungal group of the currentlycriticised chemical pesticides. Also, oddly enough, the toxic effect of aflatoxin in rats can be reversed by dosing with DDT.

Two years ago an outbreak of hepatitis, with more than 100 deaths, was reported in India, associated with the consumption of corn that was contaminated with aflatoxin. Affected people could have consumed 2 to $6 \mathrm{mg}$ daily for a month. About 1000 persons who recovered are being followed for liver cancer. 